\title{
DO STREET STATUS AND CENTRALITY MATTER FOR POST-SOCIALIST MEMORY POLICY? THE EXPERIENCE OF UKRAINIAN CITIES
}

\section{Oleksiy Gnatiuk (D) • Victoria Glybovets (D)}

Taras Shevchenko National University of Kyiv

Prospekt Hlushkova 2a, 03022 Kyiv: Ukraine

e-mails: alexgnat22@ukr.net (corresponding author) • victoriasatiya@gmail.com

\begin{abstract}
Naming and renaming of urban space often is sensitive in terms of the street location and status and implies categorization of streets according to the perceived importance of a street name. Thus, different locations in the city have different symbolic significance, and the urban toponymy could be read as a spatial projection of the societal axiological system. This article represents an attempt to study the importance of location (centrality vs. peripherality) and status (significance) of the urban public spaces in the 36 largest Ukrainian cities in terms of symbolical value and memory policy. The findings indicate that both investigated factors constitute an important tool of identity shaping and historical memory policy, but their influence and manifestation may vary considerably depending on specific historical, cultural and (geo)political conditions. Therefore, although the central parts of cities and the main urban arteries have tangibly larger symbolic significance, the toponymy of less presentable urban areas may be no less eloquent in the critical toponymy studies.
\end{abstract}

\section{Key words}

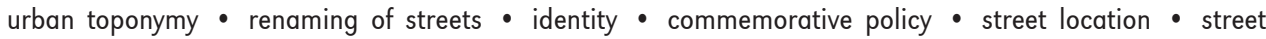
status - Ukraine

\section{Introduction}

It is widely assumed that the inhabitants generally consider some places in the city to be more significant and more valuable than others. The location of a street, its frequency of traffic and its physical length contribute to the reputation of the person or the event whose name it carries. The most important and most reputable persons in the hierarchy of values receive street names in the best locations (Azaryahu \& Kook, 2002). That's why naming and renaming of urban space often implies categorization of streets according to the perceived "importance" of a person, geographic name, idea or event: it actually means that depending on how "significant" they are considered larger or smaller, central or peripheral, busy or bleak street will be named in their honour. 
The "significance" of a certain person, historical event, idea or geographic object generally correlates with the adequate size, length, and location of a street (Crljenko, 2012). Persons and events of high axiological status are positioned, if possible, in the centre, while the lower axiological status is relocated to the periphery or thrown out onto the margins of the text (Azaryahu, 1996, 2009; Light, 2004; Dwyer \& Alderman, 2008a). Values are spatially coded within the topo-cultural structure of the city (Šakaja \& Stanić, 2017), and the cultural landscape could be read as a spatial projection of the axiological system, expressing spatial codification of values (Užarević, 1997).

The literature gives sufficient evidence that different locations in the city have different symbolic significance. That is why studies tend to focus on the central parts of cities as being more important in terms of public value and, consequently, in the commemoration process and memory policy. But is it feasible to postulate the symbolic superiority of the central (historical) parts of cities and main streets a priori in all cases without exception? Further, naming and renaming sites in more "significant" or "valuable" places can be fully evaluated and interpreted only in comparison with the "periphery", representing the other but no less interesting side of the whole toponymic process. In addition, as it follows from the arguments by Light and Young (2017), toponymy, which remains unchanged in less presentable locations or displaced there, has no less importance for understanding the features of the commemoration policy and ideological transformations than the street names in the facade parts of a city.

Thus, based on the foregoing suggestions, we may formulate the following research questions:

1. How important is the centrality of location and relative status (significance) of the urban public space in terms of symbolical value and memory policy?

2. What factor is more impactful for commemoration policy: the centrality of the urban public space in the city or its status (significance)?

3. Is it feasible to conduct critical toponymy studies focusing almost exclusively on city centres and/or main streets and squares?

One possible approach to the realization of such a research is to compare the level of concentration of the toponymy that appeared in a relatively short time frame and is related to a certain historical or ideological context in (a) the central and peripheral parts of cities; (b) among the streets of different status. The systematic statistical differences between such concentrations will point to the symbolic advantage of some locations over others. For example, if the place names associated with a certain ideology or historical period are more represented in the central parts of cities than peripheral ones, it would be logical to assume that: (1) public spaces in the central part of the city are more sensitive to renaming policy and ideological context; (2) this particular ideology or historical period is actively used by local elites as an instrument of identity and is positively perceived by the overwhelming majority of local residents. On the contrary, if a certain category of toponymy is more represented on the periphery, this may mean that it is either ideologically irrelevant or does not correspond to the current official ideology at the local and/or national levels. It should be emphasized that knowledge of the national and local historical, ideological and (geo)political context is needed to correctly interpret the identified imbalances. At the same time, if we want to identify general trends (to level the specifics of individual cases), and to interpret them comprehensively, this testing requires extensive empirical material, that is, the inclusion of many cities and many historical/ideological layers, as well as embracing cities/regions of one country, but with obvious differences in local (geo)political context.

Ukraine represents quite a suitable case for such a research. First, it provides abundant empirical material due to mass renaming of urban public spaces, taking place during the last 3 decades (starting from 1989, 
with peaks after Independence Proclamation in 1991 and the Revolution of Dignity in 2014) and resulting from firstly spontaneous and then official de-communization. Second, it deserves a special attention as a country with clear and persisting regional differences in identity and ideology. Due to the comprehensive history, internal (geo)political divisions in Ukraine are deeper rooted and manifested stronger than in any other post-socialist CEE state. Since 17th century, Ukraine was geopolitically divided between Western (more modern and pluralistic) and Orthodox-Slavic (more conservative and authoritarian) civilizations (Huntington, 1996), including actual period when both the West and Russia seek to encourage a desired historical narrative in Ukraine (Diesen \& Keane, 2017). At least 2 more or less clear geopolitical fault-lines can be traced nowadays. The first one is between the Western Ukraine, that occurred under the Soviet rule only after 1939, and the rest of the country that came through the Great Famine of 193233 and Stalin repressions, by which the peasantry and the intellectuals were annihilated as a pillar of national consciousness and the liberation movement. The second fault-line divides the centre, densely settled with predominantly agricultural population already in Cossack times, from the south-east, former "Wild Field", which started to be continuously settled only since the 19th century and undergone intense industrialization in the Soviet period, so that people there often has no other reference points for identity building than Soviet ones. These circumstances resulted in strong differences in the regional mentality, including preferences of geopolitical integration and attitudes to particular contexts and episodes of the national history, which is proved, among else, by well-marked electoral divisions of the country (Birch, 2000; Clem \& Craumer, 2008; Osipian \& Osipian, 2012). The cities in the Eastern Ukraine are typical examples of geopolitically fault-line cities, where conflict centres on issues are located at a different scale, specifically on geopolitical alignment, foreign policy direction, and on the overall character of government, while relevant disputes are largely scripted elsewhere, adding a substantial measure of volatility (Gentile, 2017, 2019). Consequently, national memory policy in the country until 2014 was contingent and contradictory, and the search for a strategy that would legitimize the new independent Ukraine and its post-Soviet elite without provoking national, linguistic and/or religious conflict, while all the time with an eye to Russia, was all about improvisation (Portnov, 2013) and oscillation between competing ideologically charged narratives of the past (Shevel, 2011). Not surprisingly, recent decommunizaton of Ukrainian urban toponymy reveals various strategies used by local and regional authorities in order to impose own version of national memory, albeit with an eye to central government policy (Gnatiuk, 2018).

\section{Literature review}

In apt words of Rose-Redwood, Alderman, and Azaryahu (2017), there are few spaces as ordinary and mundane, yet politically charged, as streets of a city. The urban streetscape is a space where different visions of the past collide in the present and competing spatial imaginaries are juxtaposed (Rose-Redwood et al., 2017), forming contemporaneous plurality (Massey, 2005). In view of this, the last three decades were marked by a gradual shift from studying place-names as primarily linguistic matter and a cultural indicator to the critical study of place naming (Azaryahu, 1986, 1996; Palonen, 1993; Alderman, 2003; Berg \& Vuolteenaho, 2009; etc.), considering toponymic processes as a key to underlying political processes and place contestation by various actors. Rose-Redwood et al. (2017) distinguish between three primary frameworks of critical toponymy, which can broadly be conceived as viewing the urban streetscape as a "city-text" (Azaryahu, 1986, 1990, 1992, 1996, 1997; Light, Nicolae, \& Suditu, 2002; Pinchevski \& Torgovnik, 2002; Light, 2004; Palonen, 2008; Azaryahu, 2011a, 2011b, 2012a, 2012b; Šakaja \& Stanić, 
2017), "cultural arena" (Berg \& Kearns, 1996; Alderman, 2002, 2003; Dwyer \& Alderman, 2008b; Rose-Redwood, 2008b; Alderman \& Inwood, 2013) and "performative space" (Rose-Redwood, 2008a, 2016; Light \& Young, 2014; Tucker \& Rose-Redwood, 2015; Crețan \& Matthews, 2016).

However, regardless of a chosen framework, the contributors agree that street names play an important role in the geopolitics of public memory (Rose-Redwood et al., 2017). In particular, naming and renaming of streets proved itself as effective way of disseminating official version of history and introducing it into everyday life of the ordinary people (Azaryahu, 2011a). Especially it is true for the geopolitically and/or ethnically divided societies, as well as for the societies under the change of political regime (Robinson, Engelstoft, \& Pobric, 2001; Stanić, Šakaja \& Slavuj, 2009). Analysing changes in urban toponymy of post-socialist countries may provide important insights on the ways in which they are awakening national consciousness among the citizens, shape their national and regional identities and rewrite their national pasts (Crljenko, 2012; Bucher et al., 2013; Stiperski et al., 2011). The role of urban toponymy in development of memories and identities after the fall of socialism is depicted and discussed, besides already cited contributions, in the works by Odaloš and Majtán (1996), Gill (2005), Crljenko (2006), Males (2006), Riznyk (2007), Krizmanić (2008), Balode (2012), Hyrych (2013), Drozdewski (2014), David and Mácha (2014), Shelekpayev (2018), etc. Several studies are focusing on (geo)politically driven toponymic changes beyond postsocialist transition context, including Spain (Faraco \& Murphy, 1997), Singapore (Yeoh, 1992, 1996), South Africa (Swart, 2008; Duminy, 2014), Kenia (Wanjiru \& Matsubara, 2017), etc.

Political regimes try to implement own version of history, accentuating persons, events and historical facts that can be useful to their rule, and trying to erase from the population's memory others that might be detrimental to them. But an important question is not only what to impose/erase, but also where to impose/erase. The issue of axiological status of urban locations and places is discussed and questioned within all mainstream frameworks of critical toponymy, as the location and the status of a street or a square often constitute a powerful tool of ideology, historical memory policy, and social justice. Sometimes cultural value of a place-name outweighs unwanted ideological connotations. E.g., David (2013) describes preservation of culturally valuable, although ideologically motivated original urbanonyms in socialist-time neighbourhoods in Czechia.

Guyot and Seethal (2007) questioned the territorial reference in respect of urban identity in South Africa in terms of the municipality as a whole, the former apartheid town, and the city centre. In Adelaide, Australia, city and state sponsored efforts to recognize Aborigines through place renaming 'overwhelmingly link indigeneity with the city's periphery, not its cultural core' and 'the landscape of indigenous (historical) presence is confined to large parkland areas' that are perceived by many people as dangerous and forbidding (Hay, Hughes, \& Tutton, 2004; cited from Alderman \& Inwood, 2013). It is for a good reason that renaming in socialist and post-socialist cities in Central and Eastern Europe usually started exactly from the city centre (Palonen, 2008; Azaryahu, 2012a; Manucharyan, 2015; etc.).

Locational context of Martin Luther King's commemoration in U.S. cities is another brilliant example revealed in the critical toponymy literature. E.g., in Danville, Virginia, officials suggested renaming after him a smaller street that had served as a focal point for members of the local civil rights movement when King had visited Danville in 1963. However, local activists rebuked this proposal arguing that the commemoration of King at an inappropriate scale of prominence represented a degradation of his memory, even when the street in question had a strong historical association with the civil rights leader. Moreover, they thought that having a road in a low-class neighbourhood named after King is simply offensive, and petitioned 
that the Central Boulevard, a major commercial thoroughfare, should be renamed in honour of King instead, so that his name could be seen by many people. In broader U.S. context, the issue was in the extent to which King's names occupy central civic spaces and are geographically accessible to the larger community, especially whites (Alderman, 2003; Alderman \& Inwood, 2013). The decision about the location of a square dedicated to the first president of democratic Croatia, Franjo Tuđman, in Zagreb, also was a problematic issue since the ruling elites were aware of the fact that the chosen location would determine the position of the former president in the hierarchy of Croatia's pantheon (Šakaja \& Stanić, 2017).

Sometimes the question of locative importance generates even more comprehensive commemoration practices, including a Croatian practice of relocating street names - their displacement to a new location in cases when there is a growing need for implementing new name and/or when there is an obvious shift in the evaluation of the importance of the existing name (Crljenko, 2012). The same refers to central-peripheral relocation of monuments or their transfer from a visible open position to an enclosed area, illustrating the changing hierarchy of values (Czepczyński, 2008; Šakaja \& Stanić, 2017). Similarly, in Bosnia and Herzegovina, the relocation of street names, inspired by the Partisan movement, from the centre to the periphery after the war in the 1990s, was a compromise for Sarajevo's citizens who did not want to see their (former) heroes leaving the city altogether (Palmberger, 2017).

That is why the majority of critical toponymy studies are based on the material almost exclusively from the central (historical) parts of the cities and/or main streets. E.g., Stiperski et al. (2011), analysing toponyms in eight Central European cities, focused on city cores in the strictest sense. They argue that the actual historical centres, the oldest and most recognizable parts of cities, most often visited by local residents and tourists, concentrating important institutions, absorbing the social and historical heritage of the cities and representing their urban identities, are the most indicative in sense of urban toponymy as every possible upgrade in urban construction, or any change, provokes great interest and subsequent discussion in professional circles and in the resident population. Thus, the question of how the city's main square and surrounding streets will be named is of first-rate importance for city authorities and the local population. Simultaneously, peripheral areas have a lesser historical importance and, therefore, are spared such public sensitivity which becomes a form of supervision; they are less often frequented and for most residents are not recognizable as important elements in their mental maps.

Bucher et al. (2013), investigating perception of identity through urban toponyms in the regional cities of Slovakia, quite similarly emphasised the sensitivity of people to the change of street names in the historical centres of the cities. These zones represent the oldest and most recognisable parts of the cities, while the periphery has less historical and cultural meaning and is not understood by people as an essential element that has formed the morphological, cultural and historical structure of the city. Thus, these authors also focused on historical centres and ignored urban periphery.

The other authors followed the same practice as well, although did not provide such a detailed explanation for the choice of the study area within the city (Drozdewski, 2014). Some special reasons to choose the central parts of cities for analysis are also presented in the literature depending on the local context, e.g., Bigon and Njoh (2017) focused on the urban centres in Sub-Saharan African cities as opposed to peripheries in order to expose their bipartite and imaginative character as well as related associations and inherent ironies.

However, in other cases selective renaming occurs, and the selection of what should and what should not be renamed also depends on locational context. Light and Young (2017) emphasise that in many instances 
(and particularly in post-socialist contexts) such renaming is not comprehensive, driven by an ideological imperative to purge the urban landscape of the symbols of the former regime. Instead, the process is more pragmatic and the emphasis is on changing particular names (those that are most ideologically inappropriate) in particular places (city centre). They designate this phenomenon as "leftover" or "residual" toponymies and suggest that more research is required to explore its extent, in particular, a greater likelihood for them to persist in the more peripheral parts of the city.

\section{Methodology}

The data about renamings (time of name change, former and new names, and, if possible, official motivation) was taken basically from the official documents, i.e. decisions of local governments and decrees of the heads of local state administrations, as well as official printed and on-line directories. In case of complicated access to official information, auxiliary sources were scrutinized such as city maps for different years and, in several cases, databases created by private organisations (e.g. Centre for Urban History of East Central Europe in Lviv, etc.).

A recent study on Ukraine (Gnatiuk, 2018) reveals modern differences in the national/ regional identity and historical memory policy based on street renaming in a large pull of Ukrainian cities in the de-communization framework after the Euromaidan of 2014. Although that study has different approach (it does not take into account the location and hierarchy of streets within the cities) and time frame, its findings are good reference point for the actual research since we may compare general patterns with newly revealed trends for central-peripheral and status dichotomies and, in this way, make our learning more comprehensive and reliable, as well as refine or question earlier conclusions on memory policy in Ukraine in the regional dimension. Therefore, we used the same set of cities (36 largest cities with a population of more than 100,000 located within government-controlled territories) and the same classification of urban toponyms by the name meaning and motivation of the name change:

I. Restored historical names.

II. Non-historical (principally new) names.

II.1. Commemorative names: toponyms in honour of certain real historic figures, organizations, institutions, events, phenomena etc. that may or may not be directly related to the given street.

II.1.a. Political and military commemorative names:

- Kievan Rus;

- Polish-Lithuanian Commonwealth;

- Cossack State;

- Russian and Austro-Hungarian Empires;

- Ukrainian Struggle for Independence in 1917-1922;

- Soviet Union;

- Ukrainian Insurgent Army (UIA) and related liberation movements;

- Independent Ukraine (including Revolution of Dignity and Donbas military conflict).

II.1.b. Other commemorative names:

- pre-Soviet (prominent people whose main activity was before the Soviet era);

- Soviet-persecuted (prominent people persecuted by Soviet authorities for several reasons);

- Soviet-favoured (prominent people having no obvious problems with the Soviet regime);

- ex-Soviet (people, related to Ukraine but constantly living outside of Ukraine in the Soviet epoch);

- post-Soviet (prominent people whose main activity was after the Soviet era).

II.2.Topographical names: toponyms indicating the location of the street relative to other elements of the urban landscape. E.g.: Poshtova (near the post 
office, "poshta" in Ukrainian); Pivdenna (in the southern part of the city, "pivden" in Ukrainian); Priorska (in the historical urban area of Priorka).

II.3.Poetic (figurative) names: toponyms that do not relate to the actual characteristics of the street and carry a degree of emotional load. E.g.: "Rankova" (Morning), "Radisna" (Cheery), "Zatyshna" (Cozy), etc.

The erasing of communist toponymy in Ukraine was heterochronic in regional dimension. While in the Western Ukraine almost all communist toponymy was removed during the early 1990s, in the Southern and Eastern Ukraine this process actually started only after 2015 in the official de-communization framework. Thus, to have sufficient empirical data from all Ukrainian regions, including Western Ukraine, we analyzed all renamings in the period from 1989-1991 (ideological shift of "perestroika" and Independence proclamation) till 2018.

Although we studied the renaming of different urban infrastructure elements, including streets, squares, avenues, etc., hereinafter, for brevity, we refer to all of them as "streets" and "street names" respectively.

The renamed streets were classified by their location and by their status, or significance, in the urban tissue. First, we divided the streets into those located in the public centre of the city, and those placed outside of its limits. The limits of the public centre were defined as an area concentrating the majority of business and social activity, playing a role of an urban show-case for residents and visitors. Typically, this area broadly coincides with the historical centre of the city. Secondly, we divided the streets according to their significance into main, secondary, and tertiary. The main streets are key urban arteries and their intersections with the main transport traffic, including the routes of public transportation. Also, this category includes urban objects with key significance in symbolic context, like main city squares or principal pedestrian streets, as well as streets serving as important tourist destinations. Respectively, secondary streets are less significant, but they still play an important role, if not for the whole city, but for any of its neighbourhoods at least. Tertiary streets typically are small lanes and passages with almost exclusively local traffic, rarely visited by inhabitants from the other parts of the city and tourists. The categories of secondary and tertiary streets are often referred to in the text together as minor streets. Classification of streets by their significance was performed using city maps, actual planning documentation (general plans, zoning, infrastructure schemes), and Google Map Platform.

Thus, each analysed street was classified by the name meaning and motivation, by centrality of its location and by its significance. Then, we defined the distribution of each class of street names by the name meaning and motivation in central-peripheral dichotomy and by the street significance. In other words, we evaluated the level of concentration of certain genetic or etymological group of toponymy in the public centre of the city vs. urban periphery and in the main streets vs. minor streets.

Let PC and PP be the percentages of given category of toponymy among the streets with the central and peripheral position respectively, and let PM, PS, PT, be the percentages of given category of toponymy among the main, secondary, and tertiary streets respectively.

The coefficient of central-peripheral distribution was calculated according to the formula:

$C C P=P C / P P$, if $P C \geq P P$, or $C C P=-P C / P P$,

if $\mathrm{PC}<\mathrm{PP}$.

If the divisor is equal to 0 , the fraction is considered to be equal to $\infty$, so that CCP in this case is equal to $+\infty$ (if $P C \geq P P$ ), or to $-\infty$ (if $P C<P P$ ).

Thus, CCP shows how many times the share of given place names in the centre exceeds the share of given place names in the periphery (if $\mathrm{CCP}>0$ ) and vice versa (if $\mathrm{CCP}<0$ ); if $\mathrm{CCP}=1$, distribution of given place names between the centre and the periphery is almost equal. 
The coefficient of status distribution was calculated according to the formula:

$\mathrm{CSt}=\left(\mathrm{PM}+0.5^{\star} \mathrm{PS}\right) /\left(0.5^{\star} \mathrm{PS}+\mathrm{PT}\right)$,

if $\mathrm{PM}+0.5^{\star} \mathrm{PS}>0.5^{\star} \mathrm{PS}+\mathrm{PT}$, or

$\mathrm{CSt}=-\left(0.5^{\star} \mathrm{PS}+\mathrm{PT}\right) /\left(\mathrm{PM}+0.5^{\star} \mathrm{PS}\right)$,

if $\mathrm{PM}+0.5^{\star} \mathrm{PS}<0.5^{\star} \mathrm{PS}+\mathrm{PT}$.

If the divisor is equal to 0 , the fraction is considered to be equal to $\infty$; thus, the total difference is considered to be $+\infty$ (if PM $+0.5^{\star} \mathrm{PS}>0.5^{\star} \mathrm{PS}+\mathrm{PT}$ ) or $-\infty\left(P M+0.5^{\star} P S<0.5^{\star} P S+P T\right)$.

Here, CSt shows how many times the share of given place names among the streets with higher status exceeds the share of given place names among the streets with lower significance (if CCP >0) and vice versa (if $\mathrm{CCP}<0$ ); if $\mathrm{CSt}=1$, distribution of given place names between the streets of different significance is almost equal.

These two indicators were calculated for main categories of toponymy (restored historical names, commemorative names, topographic names, poetic names) and for subcategories of commemorative toponymy as well.

\section{Central-peripheral distribution}

\section{General trends}

Restored historical names, with the exception of individual cities (Vinnytsia, Nikopol', Lysychansk) are concentrated in the central parts of cities throughout the whole territory of Ukraine. This is an expected trend, as the historical parts of cities had the largest reserve for the restoration of pre-existing toponymy, while peripheral parts were mostly built up in Soviet times.

Poetic names demonstrate the opposite tendency: they are concentrated almost exclusively in the peripheral parts of cities. The only exceptions are Mykolaiv and Pavlohrad, where the situation is the opposite; however, even there the relative concentration of such toponymy in the central parts is quite low.

Only in 8 out of 36 studied cities commemorative toponymy concentrates in the central parts, while in the rest it is more represented on the periphery. However, in both cases such concentration (except for Mariupol and Odesa) is not significant; therefore, in general, commemorative street names are more or less evenly distributed in the central-peripheral dimension. However, the cities of Southern and Eastern Ukraine have some trend towards a greater concentration of commemorative street names on the urban periphery.

The distribution of topographical names does not reveal a clear trend. In most cities, they are more or less evenly represented both in the center and on the periphery. Although in some cities (Poltava, Kropyvnytskyi) they are moderately concentrated in the central part, in the others (Odesa, Kherson, KamyianetsPodilskyy, Kramatorsk, Chernivtsi) they show a rather strong concentration on the periphery. However, in general, it can be assumed that there is no tendency for the central-peripheral distribution of topographical toponyms, both in national and regional dimension.

The distribution of the main categories of urban street names in the center-periphery dichotomy is presented in Figure 1.

It is hardly possible to assert the lesser importance of city centers as places of commemoration in comparison with the periphery on the basis of commemorative toponymy distribution: its relatively low proportion in central parts is conditioned, among other possible reasons, by the very high proportion of restored historical names. The results suggest that the restoration of historical place-names was the main model of de-communization in the central parts of Ukrainian cities, so the number of possible new commemorative names was substantially limited. Simultaneously, the almost complete absence of the most ideologically neutral poetic names in the central parts of the cities simply indicates the importance of the centers of the cities as places for commemoration and implementation of historical memory policy. It appears from this that the central parts of cities have a more symbolic significance, but their peripheral parts are also important areas for commemoration in terms of the number and share of commemorative toponymy. The absence of a clear trend in the 


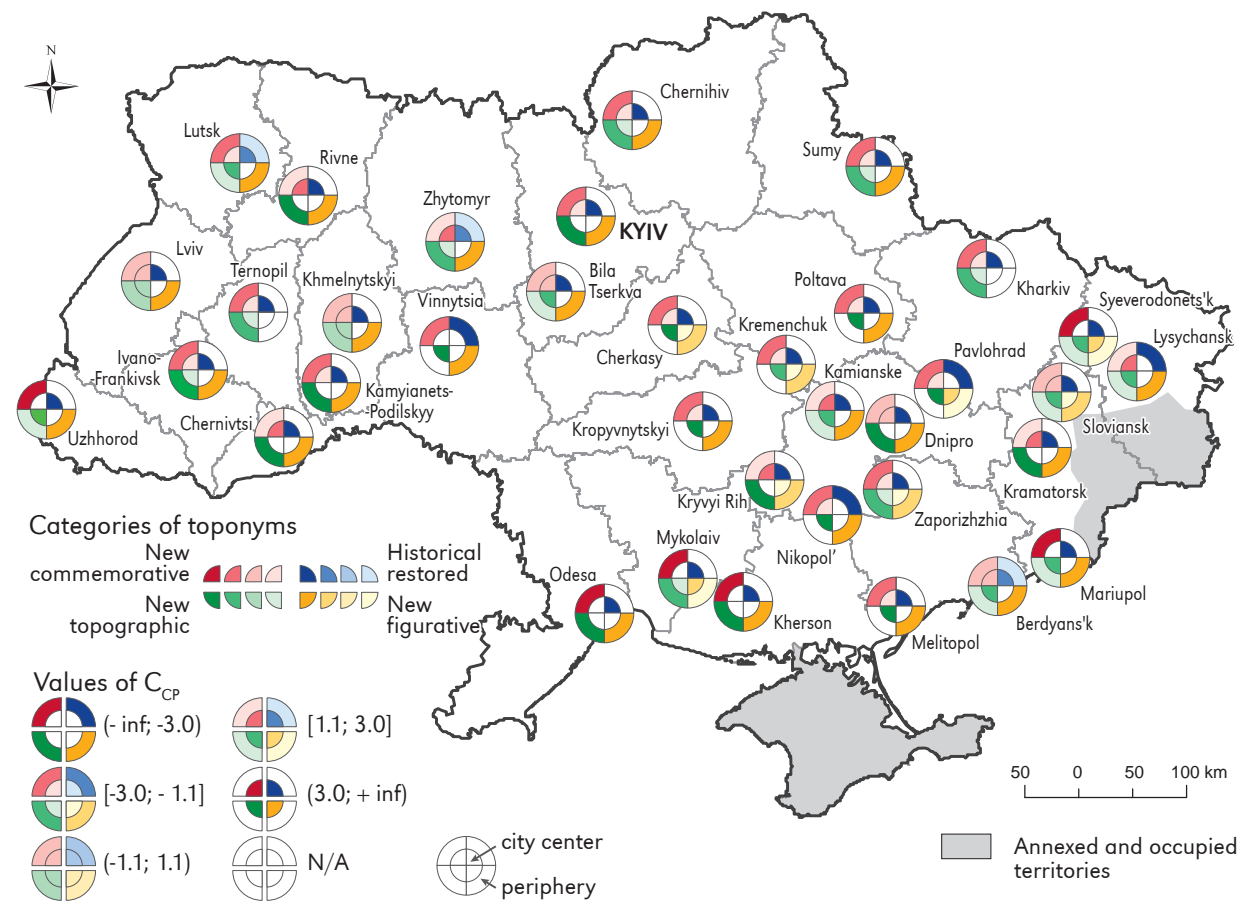

Figure 1. Central-peripheral distribution: general trends

Source: authors' analysis based on data from the city administrations.

distribution of topographical names may be interpreted as a consequence of their relative symbolic neutrality. The trend to locate symbolically neutral street names in peripheral parts of the city goes in line with findings on Riga's case, where more or less neutral (not ideological and not commemorative) toponyms are located mainly outside the city centre (Balode, 2012). The slight, but existing trend to avoid commemorative street names in the central parts of the cities in Southern and Eastern Ukraine may represent a tendency of urban toponymy deideologization in this part of the country, which is consistent with the previous findings (Gnatiuk, 2018).

\section{Military and political commemorative names}

In the national dimension, the military and political commemorative street names are evenly distributed in the central-peripheral dichotomy (Fig. 2). However, there are certain regional peculiarities: these place-names are concentrated in the central parts of cities in the Western and Central Right-Bank Ukraine, as well as in the Northeast and in Prydniprovya (Dnipropetrovsk and Zaporizhzhia regions), whereas in the Central LeftBank Ukraine and, especially, in the Black Sea region, they incline towards peripheral parts. These facts correspond to the previously revealed trend of more ideologically coloured new toponymy in the western and central regions and the desire to avoid political and ideological discourse in the South and the East, as well as the formation of the "accentuated ideologization belt" along the geopolitical fault line on the border with the occupied part of Donbas (Gnatiuk, 2018).

Street names, related to the period of Ukrainian independence, predominantly concentrate in the central parts of cities. All the vivid exceptions to this rule (Sloviansk, 


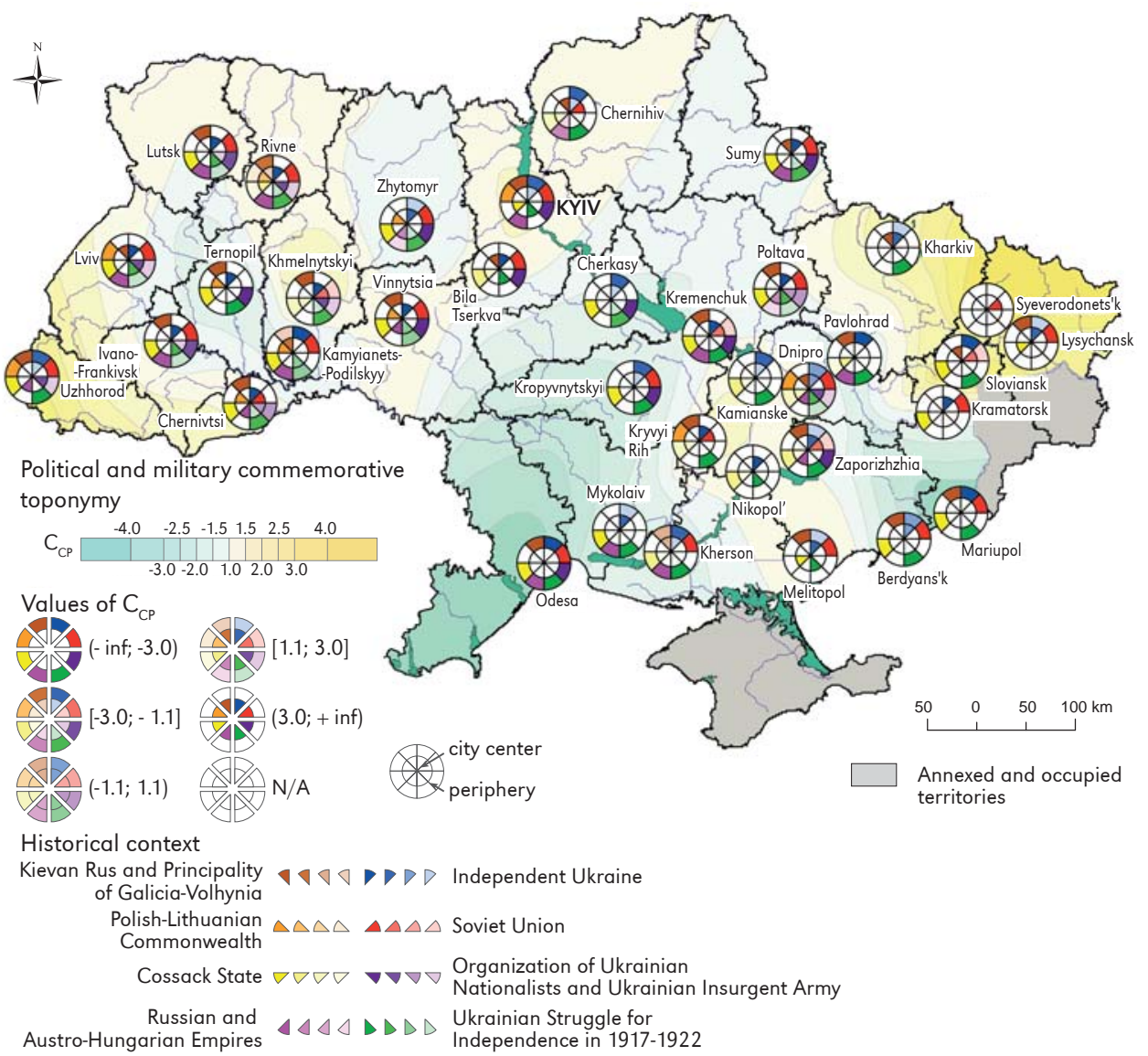

Figure 2. Central-peripheral distribution: political and military commemorative toponymy

Source: authors' analysis based on data from the city administrations.

Pavlohrad, Melitopol, Mariupol, and Odesa) are located in the South-Eastern part of the country. Thus, the commemoration of present-day heroes (predominantly the victims of the Donbas armed conflict and the memory of the Revolution of Dignity) has a noteworthy symbolic significance in all regions, is marked by a clearly demonstrative character and is intended to create a new national heroic paradigm. However, in some cities of the South-East, this modern page of national history is still perceived controversially, causing the "shyly" displacement of the corresponding toponymy to the periphery.

The street names related to the political and military figures from the Soviet era reveal quite the opposite trend, almost everywhere concentrating in the peripheral parts of cities. Thus, the memory of the Soviet era has a secondary, subordinate value. Even in the majority of cities of the Southeast, where, in accordance with the overall structure of the new toponymy, a close ideological connection with the Soviet period still remains (Gnatiuk, 2018), such names predominate quantitatively, but are "hidden" by local authorities in unrepresented parts of cities. We cannot name these toponyms as "residual", because they were newly established in the period since 1991 to replace the Communist ideological names, and they have not been actually displaced from one location (city centre) 
to another (periphery), but the essence of this phenomenon (although current Soviet-related place names differ from those existing before the de-communization campaign) has a lot in common with those described in literature (Crljenko, 2012; Light \& Young, 2017; Palmberger, 2017). Some exceptions to this rule are present throughout the territory: Syeverodonets'k and Sloviansk in Donbas, Kryvyi Rih in Prydniprovya, Zhytomyr and Chernihiv in the North, Chernivtsi and Khmelnytskyi in the West; thus, there is no clear regional trend, and each of these exceptions is individual in nature. For example, the Chernihiv region has the typical identity of the "region of Soviet partisan glory" (Melnychuk, Gnatiuk, \& Rastvorova, 2014), and the majority of Soviet-related street names in Chernihiv are devoted precisely to local figures of the Soviet partisan movement.

Cossack-related street names are mostly concentrated in the peripheral parts of the cities. Consequently, this historical period is not considered to be highly important for the formation of modern historical memory. And this pattern is observed even in the cities where the Cossack-related toponymy is quantitatively prevailing. This suggests that even in these regions the Cossack discourse may be used only to fill the gap in historical memory, but does not possess a real ideological significance. The same is true of a strata of new names related to the period of Kievan Rus and the Principality of Galicia-Volhynia.

However, the distribution of names related to the Ukrainian Struggle for Independence in 1917-1922 demonstrates clear regional tendencies. While in the West and partly in the Center of Ukraine these street names are more or less evenly represented in both the central and peripheral parts of the cities, in the cities of the South and the East they are concentrated in the periphery. The same applies to the names associated with the OUN-UIA, and they begin to be displaced on the periphery already in the Right-Bank areas, and in the Southern and Eastern regions disappear entirely. This fact is another confirmation of the ill-preparedness of the political elites and the general population in the respective regions to perceive the historical memory of these epochs as relevant; hence, it indicates the stability of the geopolitical fragmentation of the country and the absence of a national consensus on modern Ukraine as the successor of the Ukrainian Peoples Republic, Hetmanate and, especially, the struggle of the OUN-UIA.

Regarding the toponymy associated with the Polish-Lithuanian period, as well as the military and political heritage of the Russian and Austro-Hungarian empires, Romania and Czechoslovakia, there are no clear trends: everything depends on a particular city. However, certain regional trends can be identified in this case also: for example, in the cities of Galicia, where the nationalist discourse dominates, these names are superseded to the periphery of the cities, whereas in Uzhhorod and Chernivtsi, where the ideas of Ukrainian nationalism are not so popular among the local elite and general population, this toponymy is abundantly represented just in their central parts, indicating the absence of a biased attitude towards such names as colonial or alien in terms of nationality. In the West and in the Center of Ukraine, the legacy of the Polish-Lithuanian period is marked as more ideologically acceptable and built into the overall canvas of a new national identity (as evidenced by the concentration of these names in the central parts of Ternopil, Zhytomyr, Kamyianets-Podilskyy, Vinnytsia, and Rivne) in comparison with the later, imperial geopolitical entities.

\section{Other commemorative names}

In the nationwide dimension, other commemorative street names are concentrated in the peripheral parts of cities (Fig. 3). From this we can assume a more significant role of the military-political context in the modern memory policy (at least at the national level) than the cultural, scientific, artistic, religious etc. context. Exceptions to the general rule are the cities of the eastern part of the country (Donbas and Prydniprovya), as well as some cities 


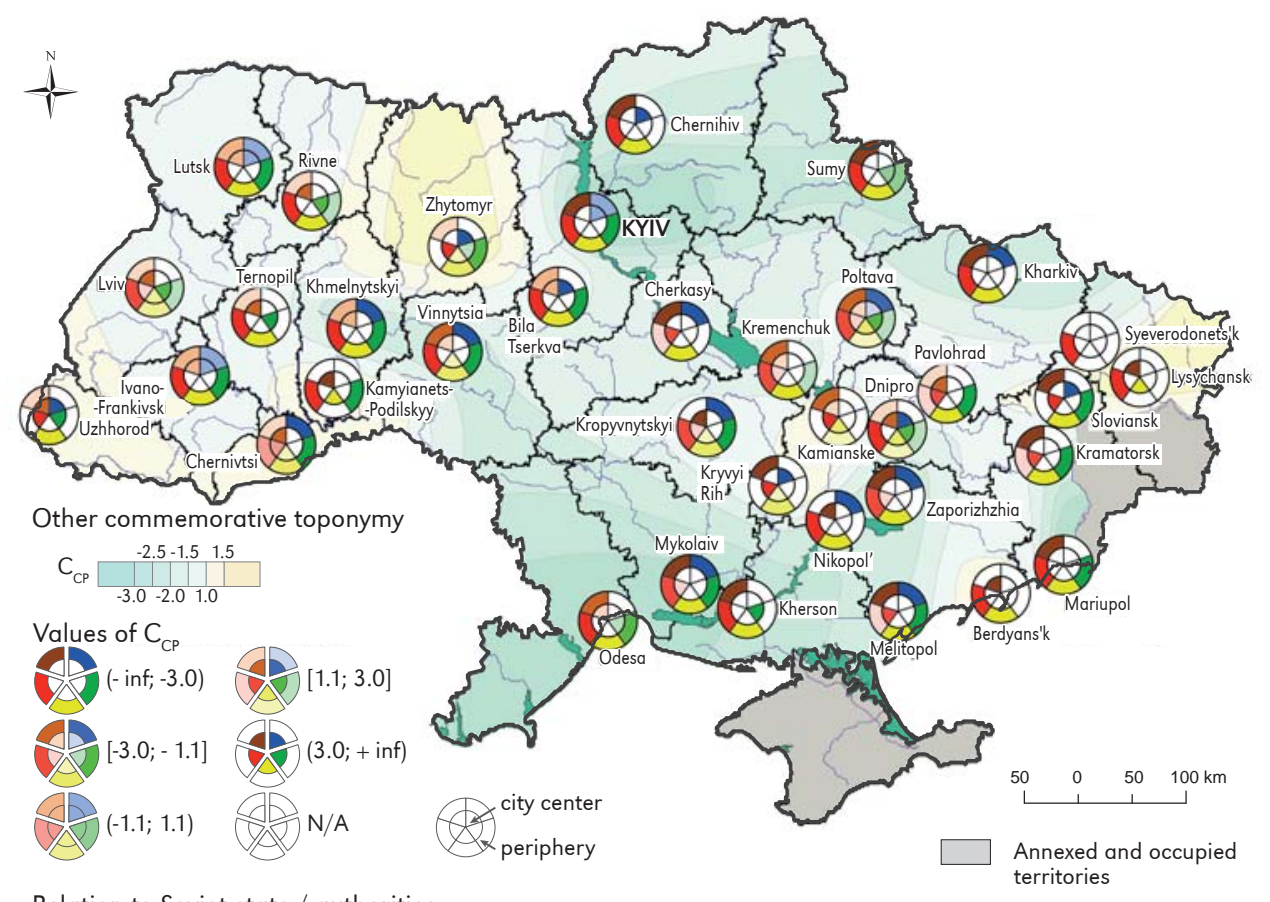

Relation to Soviet state / authorities

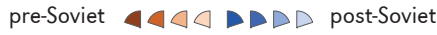

$$
\begin{aligned}
& \text { Soviet-favouried } \nabla \nabla \nabla \nabla \nabla \nabla \nabla \nabla \text { ex-Soviet }
\end{aligned}
$$$$
\Delta \Delta \Delta \Delta
$$

Soviet-persecuted

Figure 3. Central-peripheral distribution: other commemorative toponymy

Source: authors' analysis based on data from the city administrations.

in the centre (Zhytomyr) and in the West (Uzhhorod, Chernivtsi, Kamyianets-Podilskyy): it is revealing that the majority of such cases represent regions with a trend to avoid ideological flavour while renaming the streets.

In the context of individual toponymy classes, some patterns are noticeable. The Soviet-persecuted names, although characterized by peripheral concentration in the vast majority of cities in all regions, have much less disproportion of central-peripheral distribution in the Western and Central parts of the country compared to the South-East. Thus, prominent personalities that suffered from Soviet role occupy a more significant place in the historical memory policy in the West and centre comparing with the East and South. Names from the Soviet-favoured category tend towards the city's periphery throughout the whole country. Given the relatively low overall share of Soviet-favoured toponymy in the West and in the Centre and, conversely, relatively high in the South and the East, we can assume a different motivation of local elites to choose precisely peripheral commemoration place. While in the former case such place names probably lack the space in the central parts of the cities because of the obvious ideological priority for Soviet-persecuted figures, in the latter case it is probably a desire of local elites to "hide" these toponyms on the periphery in order to avoid ideologization of the urban facade and not to "irritate" the national-level 
authorities with the excessive number of neutral and positive toponymic associations with the Soviet era. Exceptions to this trend are separate industrial cities of Prydniprovya (Kryvyi Rih, Kamianske) and Donbas (Sloviansk, Kramatorsk), where the common practice was to immortalize the memory of the local industry founders, as well as some cities of the Centre and the West of the country with a relatively tolerant attitude towards the Soviet legacy compared to their neighbours (Uzhhorod and Zhytomyr).

Pre-Soviet, ex-Soviet and post-Soviet street names show a general tendency to concentrate in peripheral parts of cities, although the degree of central-peripheral imbalance differs significantly from city to city in the absence of clear regional tendencies; there are several cities where these categories of toponymy are concentrated in the central parts of cities. Thus, such names are much less sensitive to ideological context than those directly related to the Soviet period of history, and their distribution is determined more precisely by the specifics of each particular city.

\section{Distribution by street status / significance}

\section{General trends}

Restored historical names were more typical for the main streets, while poetic names are more represented among the minor ones. Thus, we have the same tendency as in the case of the central-peripheral distribution. However, in both cases, the imbalance between the main and minor streets is less pronounced than in the centre-periphery dichotomy. Obviously, central parts of the cities had much more possibilities to restore historical names, and that is why the significance of a street is a less important factor. Notably, the historical names were especially often returned to the main streets in the central parts of the cities. As for poetic names, the revealed trend is likely to indicate that such names are commonly considered inappropriate for the streets with a high significance: instead, the main street should typically have a historical name, or a topographic one, or otherwise it may be used for commemorative purposes. Nevertheless, even in this case the street status has less symbolic importance than the centrality of location.

Similarly to the center-peripheral dichotomy, the distribution of topographical street names is indifferent to the street significance and depends more on a particular city, and commemorative street names are more or less evenly distributed among the streets with different significance. However, the possibilities for commemoration among the most important streets were limited by the priority to restoration of historical toponymy.

The distribution of the main categories of urban street names among the streets of different significance is presented in Figure 4.

\section{Military and political commemorative names}

In general, there is a positive correlation between the street significance and the proportion of military and political commemorative names (Fig. 5); moreover, the factor of street significance appears to be stronger than the factor of centrality. The regional patterns are the same as for center-periphery division: military and political toponymy is more frequent among the main streets in the Western and Central RightBank Ukraine, as well as along the geopolitical fault-line stretching from the North-East (Kharkiv) through Prydniprovya to the Black Sea. For the Western part of the Black Sea Region, part of the Center of the country and the extreme East, a reverse trend is typical: military and political toponymy is associated with secondary and tertiary streets.

Certain categories of military and political toponymy reveal, with minor exceptions, identical regional patterns as in the center-peripheral distribution. In particular, this is the case of Soviet-related street names (almost everywhere - minor streets), the Ukrainian 


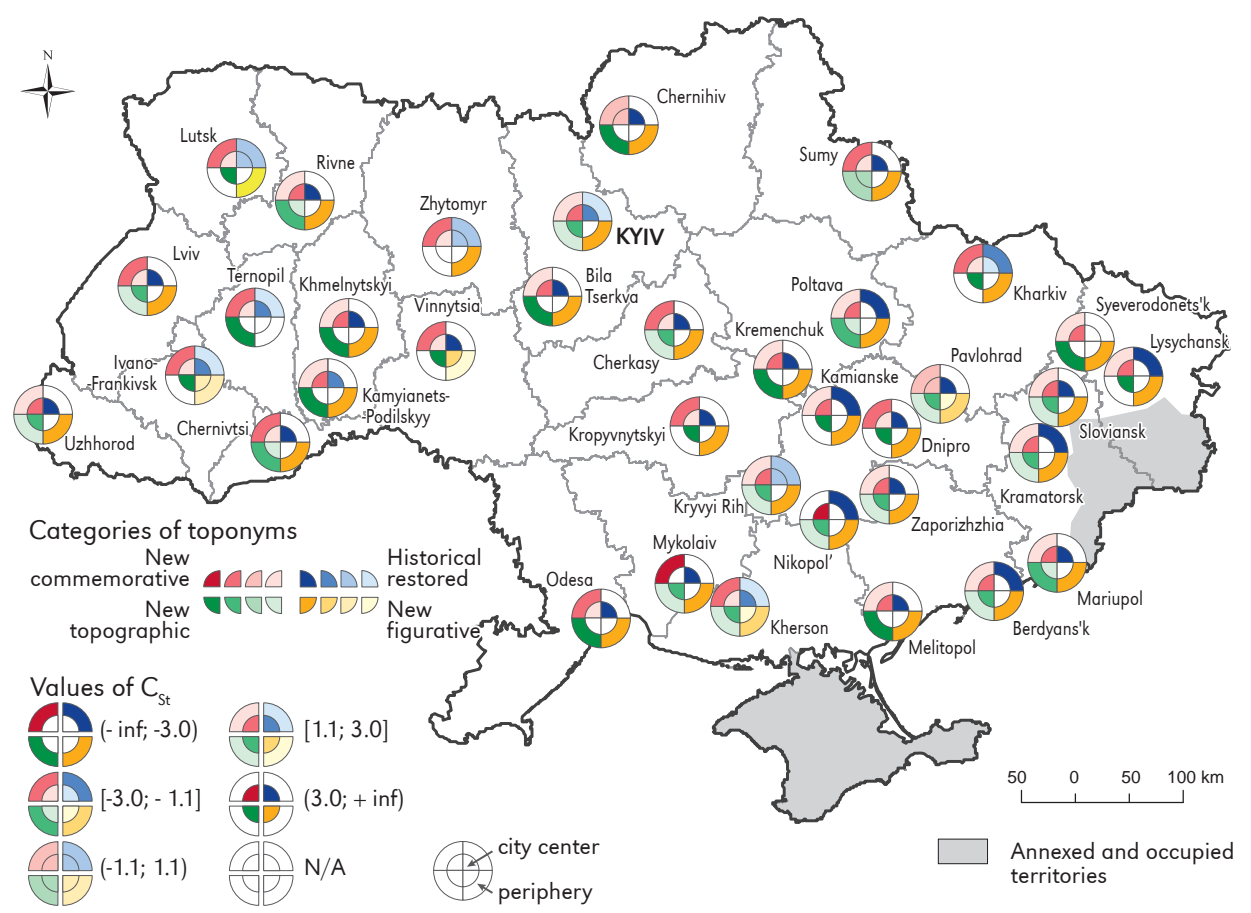

Figure 4. Street significance: general trends

Source: authors' analysis based on data from the city administrations.

Struggle for Independence in 1917-1922 and the OUN-UIA (in the West and partly in the Center of the country - almost uniform distribution, in the South and the East - mostly minor streets), the Cossack epoch (moderate or pronounced inclination towards minor streets), the period of Kievan Rus and the Principality of Galicia-Volhynia (inclination towards secondary streets, although the North-East of the country is a region with a reverse trend that is difficult to explain, possibly being an incidental coincidence), the Polish-Lithuanian and Imperial periods (no general trend, the dependence on a specific city).

The only significant difference is the names associated with the period of Ukrainian independence. First, their concentration among the main streets is not as strong as the attraction to the central parts of cities. Secondly, the regional tendency is traced: in the West and in the Center of the country such place names are more confined to the main streets, while in the South and the East, to minor ones.

\section{Other commemorative names}

In the vast majority of cities (except for the extreme East and the South-East - Donbas and Prydniprovya), other commemorative names are more typical for minor streets (Fig. 6). Soviet-favoured street names, with some exceptions, were consistently assigned to minor streets; this disproportion is particularly striking in the West of the country (historical regions of Galicia, Volhynia, and Podolia). Soviet-persecuted toponymy is also more typical for secondary streets, but the level of disproportions is substantially lower; there are numerous exceptions to this rule, and no distinct regional trends are observed. Toponymy, related to the pre-Soviet period, in general, is evenly distributed between streets with different significance, with slight - and in some 


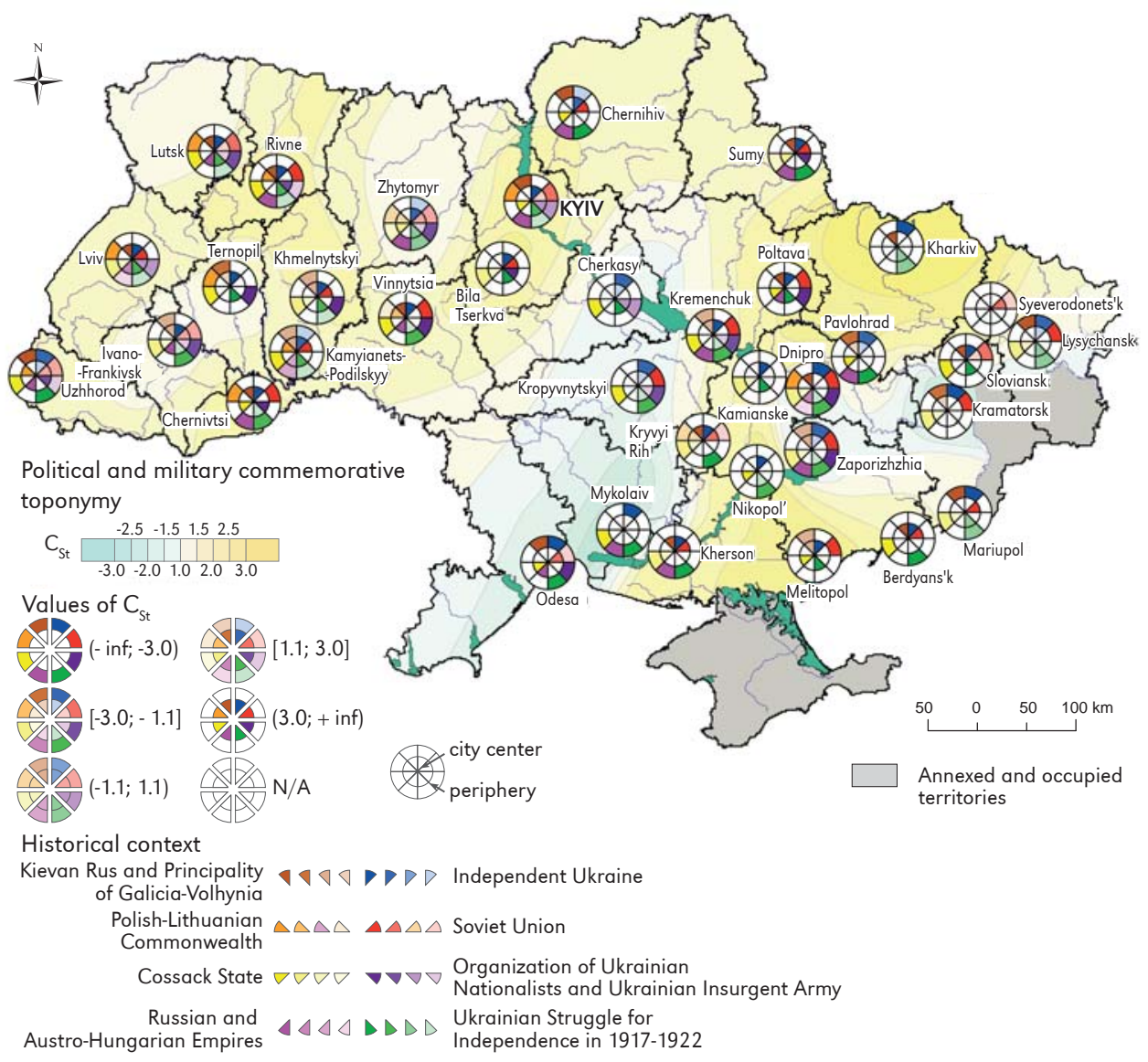

Figure 5. Street significance: political and military commemorative toponymy

Source: authors' analysis based on data from the city administrations.

cities (Mariupol, Nikopol', Kherson, Sloviansk) essential - inclination towards minor streets. The ex-Soviet toponymy is more typical of minor streets throughout the country, while post-Soviet toponymy is more typical of main streets in the Western and Central parts, and for minor streets in the Southern and Eastern parts.

\section{Do the status and centrality matter?}

The findings provide evidence pointing to the fact that both factors are important. Firstly, the structure of street names with a pronounced ideological flavour (commemorative and, in particular, military and political) and weak reference to the historical context (poetic) has a pronounced dependence on both factors. In particular, toponymy without expressive ideological meaning and bindings to the historical context is concentrated in peripheral parts of cities and is more typical of minor streets. Secondly, the differentiation of ideologically-coloured categories of toponymy has a characteristic dependence on the regional (geo)political context. In regions where the traditional ideological vector coincides with the current national mainstream, these street names gravitate towards the central parts of cities and main streets, and vice versa, in the regions where 


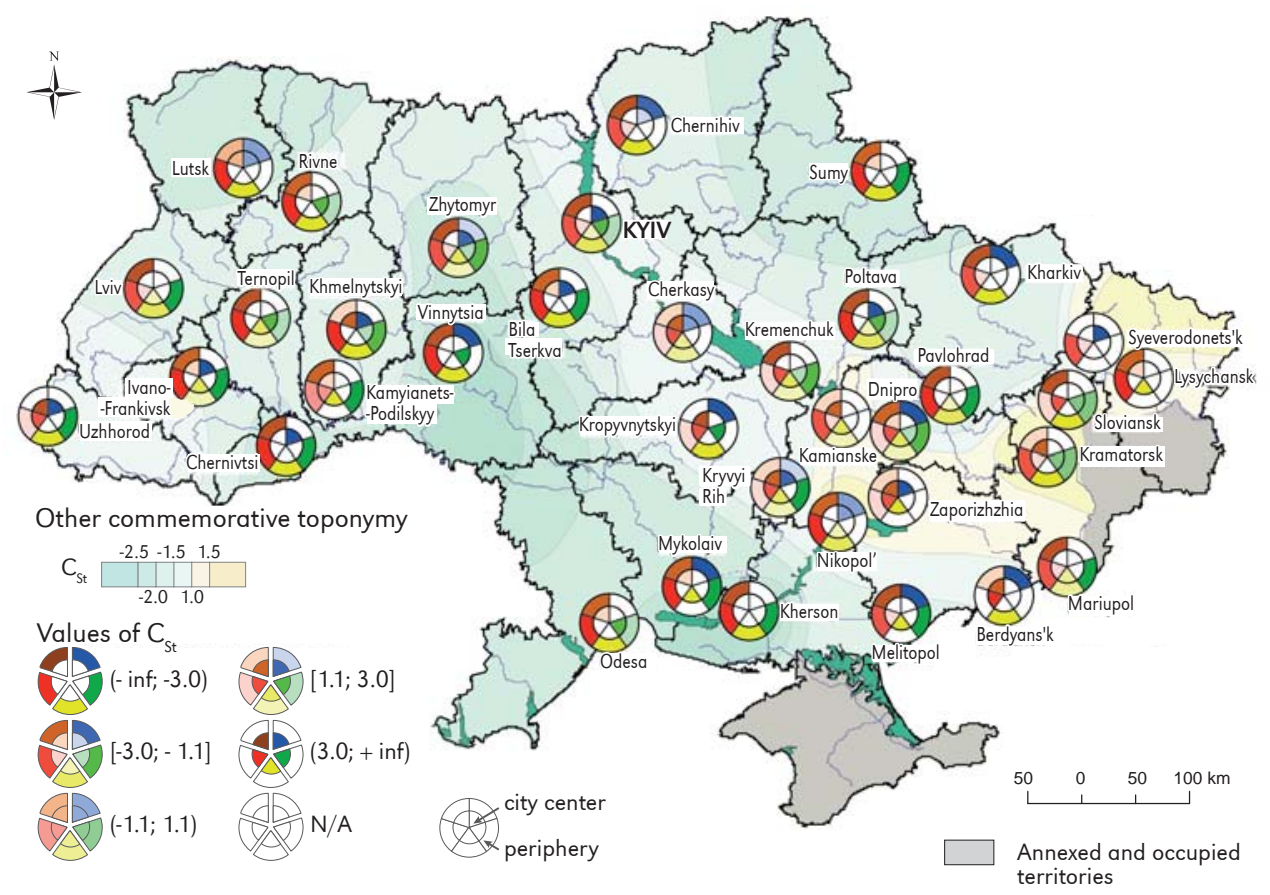

Relation to Soviet state / authorities

pre-Soviet $\triangle \triangle D D D$ post-Soviet

Soviet-favouried $\diamond \diamond \diamond \vee \triangleleft \nabla \nabla \nabla$ ex-Soviet

$\Delta \Delta \Delta \Delta$

Soviet-persecuted

Figure 6. Street significance: other commemorative toponymy

Source: authors' analysis based on data from the city administrations.

local ideology runs counter to the mainstream, they concentrate in the peripheral parts of cities and are more typical of minor streets. Thus, in the former case, such toponymy is considered as an active tool for the historical memory policy, while in the latter case, its localization indicates the absence of the established local/regional historical memory policy and the intent to secure maximum distance from any ideological discourse. Thirdly, the differentiation of certain categories of ideologically-charged names (first of all, the toponymy related to the Ukrainian struggle for independence in 1917-1922 and the OUN-UIA) is in good agreement with the regional differences in the historical memory policy identified in the previous publications
(Gnatiuk, 2018). Such names predominate among the central and main streets in the Western and central regions, where these layers of historical memory are considered to be significant and are pushed to the foreground in the regions of the South and the East, where the relevant historical context is often still treated as unproductive for the territory or even hostile.

Which factor is more important: the location of the street or its status? The absolute majority of the discovered tendencies are observed in both cases. However, the majority of detected trends are stronger in case of centre-periphery dichotomy, although military-political street names, being the most powerful commemoration instrument, are 
more sensitive to the significance of the street than to its location. This suggests that the main urban highways have a particularly significant symbolic significance independently of their location in the city. It seems that the centrality of location is more important for small streets than for large ones, while the significance is equally important for both central and peripheral streets.

Thus, our findings generally support the arguments of Azaryahu (1996, 2009), Light (2004), Stiperski et al. (2011) and Bucher et al. (2013) about historical centres of the cities as the most indicative and sensitive areas in terms of toponymic process, and their axiological status is usually higher than that of peripheral parts. Also, in agreement with Alderman (2003) we observe that the status of location as a commemoration place is sometimes even more important than its historical relevance. However, the concept of periphery should be understood here not only literally (as an outer part of the city beyond the limits of its centre), but in a broader sense as axiologically less important places, including those in the central part of a city (so called internal periphery). That is why main urban arteries are interesting study subjects all around the city, and they merit as much attention as city centres. The issue of quantitative representativeness also deserves attention: since city centres are places where the return of historical street names prevails, commemorative toponymy more often concentrates (by both quantity and percentage) precisely in the peripheral parts of cities. As for the central parts of cities, besides the study of newly appeared toponymy, attention should be paid also to the issue of restored historical names: what names have been restored, and which have not, and why? (e.g., Marin (2017) dealt with this issue discussing St. Petersburg case). To summarize, both of street categories in question deserve the highest attention as those that have the largest symbolic significance.

At the same time, when focusing only on city centres or "central" areas of the city in broader sense, one may overlook some important processes on the periphery, which may be essential for understanding the general picture. For example, the centres of Ukrainian cities, taken for the study in isolation, would not allow clearly identifying specific region in the Centre and in the South of the country, where modern identity is widely grounded (but possibly constrainedly) on the memory of the Cossack period. Moreover, investigating only presentable and decent locations, one may miss out no less indicative processes on the periphery and among the less significant streets, where the toponymy associated with undesirable (at the national and/or local levels) ideological contexts is displaced. In light of this, the suggestion to focus slightly more on peripheral parts of cities and relevant processes (Light \& Young, 2017) can be extremely useful for critical toponymy studies, at least in post-socialist countries. Moreover, in the conditions of difficult geopolitical context and high interregional diversity, especially in geopolitical fault-line cities, as in Southern and Eastern Ukraine (Gentile, 2017, 2019), the relationship between the axiological status of the person or event and respective commemoration place (e.g., a street name) (Azaryahu \& Kook, 2002; Light, 2004; Dwyer \& Alderman, 2008; Azaryahu, 2009) is not so unambiguous: in terms of ideological contradictions between central government and local elites, ideological toponymy, although one that is important for local identity, is displaced in less symbolically important locations, while key streets and squares usually receive ideologically neutral names. In this way, similar to the Balkan countries (Crljenko, 2012; Palmberger, 2017; Šakaja \&Stanić, 2017), local political elites in Ukraine are trying to find a compromise with citizens and to leave their "former" heroes in the city, with the only difference that in Ukrainian case we observe not a direct relocation of street names but spatial (centre-peripheral) relocation of context-related toponymy strata. The elements of the "unwanted socialist past" are preserved but obscured or, at least, not specially emphasised (Young \& Kaczmarek, 2008); in this way local elites offer resistance 
to the dominant anti-Soviet counter-narrative stemming from Kyiv (Gentile, 2017).

Various archaeological layers of meanings superimposed over time in the cityscape (Azaryahu, 1992) are not geographically static but may move from the one part of the city to another under their re-evaluation. Interestingly, under such conditions, a rather heterogeneous "company" of the ideologically opposite historical figures, events and ideas is formed on the urban periphery, since place names that are acceptable for national mainstream but ideologically alien to the local elite, also concentrate exactly on the periphery. That is why critical toponymy studies of divided cities (in particular geopolitically fault-line cities like the cities from the East and South of Ukraine) (Gentile, 2017, 2019), where ideological and political division, inscribed in the "palimpsest" of the city-text (Parkhurst-Ferguson, 1988), is sensitive to centre-peripheral axiological relations of places, require holistic approach embracing the city in its integrity.

\section{National and regional specifics of historical memory policy in Ukraine in view of the findings}

New data have confirmed the preservation of more or less pronounced geopolitical faultlines within the country and the coexistence of different regional models of historical memory policy (Katchanovski, 2006; Osipian \& Osipian, 2012; Portnov, 2013; Gnatiuk, 2018). Moreover, they somewhat clarify the previous assumptions about these models. It is evident that in the Western and partly Central Ukraine the historical memory policy is clearly based on the national liberation movements of the 20th century. In this part of the country, the central parts of the cities and their main streets constitute a kind of an enhanced copy of the general tendencies in an entire city. Simultaneously, in the South, the East and partly in the Centre of the country, the policy of historical memory is only at the stage of formation, and existing views on national history, including various
Soviet-rooted stereotypes, often come into conflict with the modern official interpretation of history. Therefore, in the respective regions, an alternative form of a new national identity is being sought, including in the light of the local historical and cultural context, but at the same time there is a desire to distance from any vivid forms of ideology. As a result, even the most locally acceptable military and political street names, related to the Cossack epoch and the Soviet period, tend to concentrate in less presentable parts of cities. Since the Soviet period of history is officially not in fashion nowadays, we observe the shyly concealment of toponymy, which creates positive mental associations with the Soviet period (even allowed by official legislation). In the light of the new results, we can more confidently assume that abundance of "Cossack" street names in the centre and partially east and south of the country (Gnatiuk, 2018) is rather an attempt to fill the identity gap with the most acceptable historical context than an indicator of the already formed "Cossack" identity of the respective region. However, new data confirm the existence of a belt along the geopolitical fault-line from Slobozhanshchyna through Prydniprovya to the Black Sea, where the commemorative practices follow an official mainstream (Gnatiuk, 2018).

The findings also suggest that military and political toponymy was the main tool of the historical memory policy in the independent Ukraine. The context of culture, education, religion, and art occupies a subordinate position and comes to the foreground when it becomes possible to emphasize the conflict between these prominent individuals and the Communist regime (this can be achieved using Soviet-persecuted street names). Referencing to local or regional "Golden Age", in some cases in the form of "Europeannes" (Bitusikova, 1998; Young \& Light, 2001; Czarniawska, 2002; Grodach, 2002; Gubar \& Herlihy, 2005; Petro, 2005; Palonen, 2008; Young \& Kaczmarek, 2008), seem to be successful in explaining regional differences in contemporary commemoration practices in Ukrainian 
regions; however, this "Golden Age" may be hidden both in the centre or the periphery of the city depending on regional and local context. Both general strategy of toponymy changing and centre-peripheral (in broad sense) patterns in the cities of Eastern and Southern Ukraine display, despite of some similarity, significant differences between them, supporting arguments about volatile course of conflict in geopolitically divided cities (Gentile, 2017).

\section{Conclusions}

The findings indicate that the factors under investigation (centrality and status of urban public space) are clearly an important tool of identity shaping and historical memory policy. But the concrete mechanism of employing this tool, including the consequences of different symbolic weights of different locations within a single city, may vary considerably depending on specific historical, cultural and (geo)political conditions. Particularly sophisticated interdependence between the axiological status of the commemorated object and the location is typical of geopolitical fault-line cities. For example, in Ukraine, facade parts of such cities are subjects to deidologization, while ideologically coloured names from different parts of the spectrum are "displaced" to less symbolically important locations. The central and peripheral parts of cities are two interconnected elements of one whole; respectively, the toponymy of less presentable parts of the city may be no less eloquent in the critical toponymy studies than the place names given to central and/or main streets. Thus, the findings point to the importance of integrated studies of the urban symbolic space and its transformations, although certain case studies could be also very illustrative depending on their focus and research purpose.

Editors' note:

Unless otherwise stated, the sources of tables and figures are the authors', on the basis of their own research.

\section{References}

Alderman, D. (2002). Street names as memorial arenas: The reputational politics of commemorating Martin Luther King in a Georgia County. Historical Geography, 30, 99-120.

Alderman, D.H. (2003). Street names and the scaling of memory: The politics of commemorating Martin Luther King, Jr within the African American community. Area, 35(2), 163-173. https://doi.org/10.1111/1475-4762.00250

Alderman, D., Inwood, J. (2013). Street naming and the politics of belonging: Spatial injustices in the toponymic commemoration of Martin Luther King Jr. Social and Cultural Geography, 14(2), 211-233. https://doi.org/10.1080/14649365.2012.754488

Azaryahu, M. (1986). Street names and political identity. The case of east Berlin. Journal of Contemporary History, 21(4), 581-604. https://doi.org/10.1177/002200948602100405

Azaryahu, M. (1990). Renaming the past: Changes in 'city-text' in Germany and Austria 1945-1947. History \& Memory, 2(2), 32-53.

Azaryahu, M. (1992). The purge of Bismarck and Saladin: The renaming of streets in East Berlin and Haifa, a comparative study in culture-planning. Poetics Today, 13(2), 351-367. https://doi.org/10.2307/1772537

Azaryahu, M. (1996). The power of commemorative street names. Environment and Planning D, 14(3), 311-330. https://doi.org/10.1068/d140311

Azaryahu, M. (1997). German reunification and the politics of street names: The case of East Berlin. Political Geography, 16(6), 479-493. https://doi.org/10.1016/S0962-6298(96)00053-4 
Azaryahu, M. (2009). Naming the past: The significance of commemorative street names. In L. Berg, J. Vuolteenaho (Eds.), Critical toponymies: The contested politics of place naming (pp. 53-70). Farnham: Ashgate.

Azaryahu, M. (2011a). The critical turn and beyond: The case of commemorative street naming. An International E-Journal for Critical Geographies, 10(1), 28-33.

Azaryahu, M. (2011b). The politics of commemorative street renaming: Berlin 1945-1948. Journal of Historical Geography, 37(4), 483-492. https://doi.org/10.1016/j.jhg.2011.06.001

Azaryahu, M. (2012a). Renaming the past in post-Nazi Germany: Insights into the politics of street naming in Mannheim and Potsdam. Cultural Geographies, 19(3), 385-400. https://doi.org/10.1177/1474474011427267

Azaryahu, M. (2012b). Rabin's Road: The Politics of toponymic commemoration of Yitzhak Rabin in Israel. Political Geography, 31(2), 73-82. https://doi.org/10.1016/j.polgeo.2011.10.006

Azaryahu, M., Kook, R. (2002). Mapping the nation: Street names and Arab Palestinian identity: three case studies. Nations and Nationalism, 8(2), 195-213. https://doi.org/10.1111/1469-8219.00046

Balode, L. (2012). Place-names in the urbanonymy of Riga: mark of identity. Studii si Cercetari de Onomastica si Lexicologie, 5(1-2), 17-28.

Berg, L., Kearns, R. (1996). Naming as norming: 'race', gender, and the identity politics of naming places in Aotearoa/New Zealand. Environment and Planning D: Society and Space, 14(1), 99-122. https://doi.org/10.1068/d140099

Berg, L., Vuolteenaho, J. (Eds.). (2009). Critical toponymies: The contested politics of place naming. Farnham: Ashgate.

Bigon, L., Njoh, A.J. (2017). Toponymic complexities in Sub-Saharan African cities. Informative and symbolic aspects from past to present. In R. Rose-Redwood, D. Alderman, M. Azaryahu (Eds.), The political life of urban streetscapes: naming, politics, and place (pp. 202-217). Abingdon, U.K.: Routledge. https://doi.org/10.4324/9781315554464-12

Birch, S. (2000). Interpreting the regional effect in Ukrainian politics. Europe-Asia Studies, 52(6), 1017-1041. https://doi.org/10.1080/09668130050143815

Bitusikova, A. (1998). Transformations of a city centre in the light of ideologies: The case of Banska Bystrica, Slovakia. International Journal of Urban and Regional Research, 22, 614-622. https://doi.org/10.1111/1468-2427.00165

Bucher, S., Matlovič, R., Lukáčová, A., Harizal, B., Matlovičová, K., Kolesárová, J., Čermákov, L., Michalko, M. (2013). The perception of identity through urban toponyms in the regional cities of Slovakia. Anthropological Notebooks, 19(3), 23-40.

Clem, R.S., Craumer, P.R. (2008). Orange, Blue and White, and Blonde: The electoral geography of Ukraine's 2006 and 2007 Rada elections. Eurasian Geography and Economics, 49(2), 127-151. https://doi.org/10.2747/1539-7216.49.2.127

Crețan, R., Matthews, P. (2016). Popular responses to city-text changes: Street naming and the politics of practicality in a post-socialist martyr city. Area, 48(1), 92-102. https://doi.org/10.1111/area.12241

Crljenko, I. (2006). Regionalni identitet u urbanom pejsažu sjevernog hrvatskog primorja: prostorna i značenjska analiza gradske toponimije. (Typescript). University of Zagreb.

Crljenko, I. (2012). The renaming of streets and squares in post-Socialist Croatian towns. Language and Society, 3, 230-241. http://dx.doi.org/10.30970/ls.3.1811

Czarniawska, B. (2002). Remembering while forgetting: The role of automorphism in city management in Warsaw. Public Administration Review, 62, 163-173. https://doi.org/10.1111/0033-3352.00167

Czepczyński, M. (2008). Cultural landscapes of post-socialist cities. Aldershot: Ashgate. https://doi.org/10.4324/9781315575315

David, J. (2013). Street names - between ideology and cultural heritage. Acta Onomastica, 54(1), 53-61.

David, J., Mácha, P. (2014). Názvy míst. Pamět, identita a kulturní dědictví. Ostrava. 
Diesen, G., Keane, C. (2017). The two-tiered division of Ukraine: Historical narratives in nation-building and region-building. Journal of Balkan and Near Eastern Studies, 19(3), 313-329. https://doi.org/10.1080/19448953.2017.1277087

Drozdewski, D. (2014). Using history in the streetscape to affirm geopolitics of memory. Political Geography, 42, 66-78. https://doi.org/10.1016/j.polgeo.2014.06.004

Duminy, J. (2014). Street renaming, symbolic capital, and resistance in Durban, South Africa. Environment and Planning D: Society and Space, 32(2), 310-328. https://doi.org/10.1068/d2112

Dwyer, O., Alderman, D.H. (2008a). Civil rights memorials and the geography of memory. Chicago: The Center for American Places at Columbia College.

Dwyer, O., Alderman, D. (2008b). Memorial landscapes: Analytic questions and metaphors. GeoJournal, 73(3), 165-178. https://doi.org/10.1007/s10708-008-9201-5

Faraco, J., Murphy, M. (1997). Street names and political regimes in an Andalusian town. Ethnology, 36(2), 123-148. https://doi.org/10.2307/3774079

Gentile, M. (2017). Geopolitical fault-line cities. In A. Pikulicka-Wilczewska and G. Uehling (Eds.), Migration and the Ukraine crisis: A two-country perspective (pp. 6-24). Bristol: E-International Relations.

Gentile, M. (2019). Geopolitical fault-line cities in the world of divided cities. Political Geography, 71, 126138. https://doi.org/10.1016/j.polgeo.2019.03.002

Gill, G. (2005). Changing symbols: The renovation of Moscow place names. The Russian Review, 64, 480-503. 10.1111/j.1467-9434.2005.00371.x

Gnatiuk, O. (2018). The renaming of streets in post-revolutionary Ukraine: Regional strategies to construct a new national identity. Acta Universitatis Carolinae Geographica, 53(2), 119-136. https://doi.org/10.14712/23361980.2018.13

Grodach, C. (2002). Reconstituting identity and history in post-war Mostar, Bosnia-Herzegovina. City, 6, 61-82. https://doi.org/10.1080/13604810220142844

Gubar, O., Herlihy, P. (2005). The persuasive power of the Odessa Myth. Harvard University. Retrieved from http://www.fas.harvard.edu/ ces-lib/docs [9 August 2019].

Guyot, S., Seethal, C. (2007). Identity of place, places of identities, change of place names in post-apartheid South Africa. The South African Geographical Journal, 89(1), 55-63. https://doi.org/10.1080/03736245.2007.9713873

Hay, I., Hughes, A., Tutton, M. (2004). Monuments, memory and marginalisation in Adelaide's Prince Henry Gardens. Geografiska Annaler B, 86(3), 201-216. https://doi.org/10.1111/j.0435-3684.2004.00162.x

Huntington, S. P. (1996). The clash of civilizations and the remaking of world order. New York: Simon and Schuster.

Hyrych, I. (2013). Suchasna kyjivska toponimika jak vyjav istorychnoji svidomosti. Nacionalna ta istorychna pamjat, 8, 133-141.

Katchanovski, I. (2006). Regional political divisions in Ukraine in 1991-2006. Nationalities Papers, 34(5), 507-532. https://doi.org/10.1080/00905990600952939

Krizmanić, A. (2008). Razvitak uličnog nazivlja: imena ulica, trgova i parkova 2008 s prijašnjim nazivima. In A. Krizmanić (Ed.), Stradarij grada Pule (pp. 85-356). Pula: Histria Croatica CASH.

Light, D. (2004). Street names in Bucharest, 1990-1997: Exploring the modern historical geographies of postsocialist change. Journal of Historical Geography, 30(1), 154-172. https://doi.org/10.1016/s0305-7488(02)00102-0

Light, D., Nicolae, I., Suditu, B. (2002). Toponymy and the communist city: Street names in Bucharest, 1948-1965. GeoJournal, 56(2), 135-144. https://doi.org/10.1023/A:1022469601470

Light, D., Young, C. (2014). Habit, memory and the persistence of socialist-era street names in postsocialist Bucharest, Romania. Annals of the Association of American Geographers, 104(3), 668-685. https://doi.org/10.1080/00045608.2014.892377 
Light, D., Young, C. (2017). The politics of toponymic continuity. The limits of change and the ongoing lives of street names. In R. Rose-Redwood, D. Alderman, M. Azaryahu (Eds.), The political life of urban streetscapes: Naming, politics, and place (pp. 185-201). Abingdon, U.K.: Routledge.

Manucharyan, N. (2015). The reflection of communist ideology in the street renaming policy in Soviet Yerevan (1921-1939). Analytical Bulletin, 8, 122-155.

Males, L. (2006). Karta mista: symvolichnyj prostir upravlinnia. In Suchasni suspilni problemy u vymiri sociolohiji upravlinnia. Materialy druhoji naukovoji konferenciji (pp. 169-174). Donetsk.

Marin, A. (2017). Toponymic changes as temporal boundary-making. Street renaming in Leningrad/ St. Petersburg. In R. Rose-Redwood, D. Alderman, M. Azaryahu (Eds.), The political life of urban streetscapes: naming, politics, and place (pp. 132-149). Abingdon, U.K.: Routledge.

Massey, D. (2005). For space. London: Sage Publications.

Melnychuk, A., Gnatiuk, O., Rastvorova, M. (2014). Use of territorial identity markers in geographical researches. Scientific Annals of "Alexandru loan Cuza" University of lasi - Geography Series, 60(1), 157184. http://dx.doi.org/10.15551/scigeo.v60i1.274

Niculescu-Mizil, A-M. (2014). (Re)naming streets in contemporary Bucharest: From power distribution to subjective biography. Analize: Journal of Gender and Feminist Studies, 3, 69-94.

Odaloš, P., Majtán, M. (Eds.). (1996). Urbanonymá v kontexte histórie a súčasnosti. Materiály z onomastického kolokvia (Banská Bystrica 3-5 septembra 1996). Banská Bystrica - Bratislava: Pedagogická fakulta UMB - Fakulta humanitných vied UMB - Jazykovedný ústav L.S.Stúra SAV.

Osipian, A. L., Osipian, A. L. (2012). Regional diversity and divided memories in Ukraine: Contested past as electoral resource, 2004-2010. East European Politics and Societies, 26(3), 616-642. https://doi.org/10.1177/0888325412447642

Palmberger, M. (2017). Nationalizing the streetscape: The case of street renaming in Mostar, Bosnia and Herzegovina. In R. Rose-Redwood, D. Alderman, M. Azaryahu (Eds.), The political life of urban streetscapes: naming, politics, and place (pp. 168-184). Abingdon, U.K.: Routledge.

Palonen, E. (2008). The city-text in post-communist Budapest: Street names, memorials, and the politics of commemoration. GeoJournal, 73(3), 219-230. https://doi.org/10.1007/s10708-008-9204-2

Palonen, K. (1993). Reading street names politically. In K. Palonen, T. Parvikko (Eds.), Reading the Political (pp. 103-121). Helsinki: The Finnish Political Science Association.

Parkhurst-Ferguson, P. (1988). Reading city streets. The French Review, 61(3), 386-397.

Petro, N.N. (2005). Old Russia's new city: Novgorod the Great as a political model. Harvard University. Retrieved from http://www.fas.harvard.edu/ ces-lib/docs [9 August 2019].

Pinchevski, A., Torgovnik, E. (2002). Signifying passages: The signs of change in Israeli street names. Media, Culture and Society, 24(3), 365-388. https://doi.org/10.1177/016344370202400305

Portnov, A. (2013). Memory wars in post-Soviet Ukraine (1991-2010). In U. Blacker, A. Etkind, J. Fedor (Eds.), Memory and theory in Eastern Europe (pp. 233-254). New York: Palgrave Macmillan. https://doi.org/10.1057/9781137322067_12

Riznyk, O. (2007). Toponimichnyj landshaft Kyjeva i problemy derzhavnoji toponimichnoji polityky. Retrieved from http://tram.mashke.org/files/AMY/books/riznik_topolandshaft_2007.pdf [9 August 2019].

Robinson, G.M., Engelstoft, S., Pobric, A. (2001). Remaking Sarajevo: Bosnian nationalism after the Dayton accord. Political Geography, 20, 957-980. https://doi.org/10.1111/j.1467-9663.2006.00517.x

Rose-Redwood, R. (2008a). 'Sixth Avenue is now a memory': Regimes of spatial inscription and the performative limits of the official city-text. Political Geography, 27(8), 875-894.

https://doi.org/10.1016/j.polgeo.2008.11.002

Rose-Redwood, R. (2008b). From number to name: Symbolic capital, places of memory, and the politics of street renaming in New York City. Social \& Cultural Geography, 9(4), 431-452.

https://doi.org/10.1080/14649360802032702 
Rose-Redwood, R. (2016). 'Reclaim, rename, reoccupy': Decolonizing place and the reclaiming of PKOLS. ACME: An International E-Journal for Critical Geographies, 15(1), 187-206.

Rose-Redwood, R., Alderman, D., Azaryahu, M. (2017). The urban streetscape as political cosmos. In R. Rose-Redwood, D. Alderman, M. Azaryahu (Eds.), The political life of urban streetscapes: Naming, politics, and place (pp. 1-24). Abingdon, U.K.: Routledge.

Šakaja, L., Stanić, J. (2017). The spatial codification of values in Zagreb's city-text. In R. Rose-Redwood, D. Alderman, M. Azaryahu (Eds.), The political life of urban streetscapes: Naming, politics, and place (pp. 151-167). Abingdon, U.K.: Routledge.

Shelekpayev, N. (2018). Is name destiny? On some cases of post-Soviet street-naming in Almaty and Astana. In J. Ira, J. Janáč (Eds.), Materializing identities in socialist and post-socialist cities (pp. 99-116). Prague: Karolinum Press.

Shevel, O. (2011). The politics of memory in a divided society: A comparison of post-Franco Spain and postSoviet Ukraine. Slavic Review, 70(1), 137-164. https://doi.org/10.5612/slavicreview.70.1.0137

Stiperski, Z., Lorber, L., Heršak, E., Ptaček, P., Górka, Z., Kołoś, A., Lončar, J., Faričić, J, Miličević, M., Vujaković, A., Hruška, A. (2011). Identity through urban nomenclature: Eight Central European cities. Geografisk Tidsskrift - Danish Journal of Geography, 111(2), 181-194. https://doi.org/10.1080/00167223.2011.10669532

Stanić, J., Šakaja, L., Slavuj, L. (2009). Preimenovanja zagrebačkih ulica i trgova. Migracijske i etničke teme, 25(1-2), 89-124.

Swart, M. (2008). Name changes as symbolic reparation after transition: the examples of Germany and South Africa. German Law Journal, 9(2), 105-120. https://doi.org/10.1017/s2071832200006337

Tucker, B., Rose-Redwood, R. (2015). Decolonizing the map? Toponymic politics and the rescaling of the Salish Sea. The Canadian Geographer, 59(2), 194-206. https://doi.org/10.1111/cag.12140

Užarević, J. (1997). Prostorno kodiranje vrijednosti. Tijelo i prostor. In M. Medarić (Eds.), Hijerarhija (pp. 19-27). Zagreb: ZZK.

Wanjiru, M.W., Matsubara, K. (2017). Street toponymy and the decolonisation of the urban Landscape in post-colonial Nairobi. Journal of Cultural Geography, 34(1), 1-23.

https://doi.org/10.1080/08873631.2016.1203518

Yeoh, B. (1992). Street names in colonial Singapore. Geographical Review, 82(3), 313-322. https://doi.org/10.2307/215354

Yeoh, B. (1996). Street-naming and nation-building: Toponymic inscriptions of nationhood in Singapore. Area, 28(3), 298-307.

Young, C., Kaczmarek, S. (2008). The socialist past and postsocialist urban identity in Central and Eastern Europe. The case of Łódź, Poland. European Urban and Regional Studies, 15(1), 53-70. https://doi.org/10.1177/0969776407081275

Young, C., Light, D. (2001). Place, national identity and post-socialist transformations: An introduction. Political Geography, 20(8), 941-955. https://doi.org/10.1016/S0962-6298(01)00039-7 